\title{
Six DNA polymorphisms in the low density lipoprotein receptor gene: their genetic relationship and an example of their use for identifying affected relatives of patients with familial hypercholesterolaemia
}

Steve Humphries, Linda King-Underwood, Vilmunder Gudnason, Mary Seed, Sophie Delattre, Veronique Clavey, Jean-Charles Fruchart

\begin{abstract}
We have determined the relative allele frequency and estimated linkage disequilibrium between six DNA polymorphisms of the low density lipoprotein (LDL) receptor gene. Polymorphisms were detected using the enzymes SfaNI, TaqI, StuI, HincII, AvalI, and Ncol after DNA amplification by the polymerase chain reaction. Strong linkage disequilibrium was detected between many of the pair wise comparisons in a sample of 60 patients heterozygous for familial hypercholesterolaemia (FH). Using the enzymes HincII, NcoI, and SfaNI, $85 \%$ of patients were heterozygous for at least one polymorphism and thus potentially informative for cosegregation studies. The polymorphisms were used to follow the inheritance of the defective allele of the LDL receptor gene in the relatives of a patient with FH. Assays of LDL receptor activity on lymphoblastoid cell lines from two members of the family was used to confirm that the proband, but not the hypercholesterolaemic brother, had a defect in the LDL receptor. In the family, none of the children had inherited the allele of the LDL receptor gene inferred to be defective. The problems associated with this cosegregation approach to identify relatives of patients with a clinical diagnosis of $\mathrm{FH}$ are discussed.

(f Med Genet 1993;30:273-9)
\end{abstract}

Familial hypercholesterolaemia $(\mathrm{FH})$ is a common inherited disease with a frequency of about 1 in $500 .{ }^{1}$ The disorder is characterised clinically by a raised concentration of low density lipoprotein (LDL) cholesterol in blood, tendon xanthomata, an increased risk of myocardial infarction, and genetically by autosomal dominant inheritance. Studies performed over 15 years ago in the UK and the $\mathrm{USA}^{23}$ indicate that 5 to $10 \%$ of subjects suffering a myocardial infarction before the age of 55 years may have $\mathrm{FH}$. Hypercholesterolaemia is treatable both by dietary measures and by drug therapy, and it is therefore important to identify subjects who have $\mathrm{FH}$ so that appropriate treatment can be offered to reduce their subsequent risk of myocardial infarction.
$\mathrm{FH}$ results from different genetic defects in a cell surface receptor which normally controls the uptake of plasma $\mathrm{LDL},{ }^{45}$ and the cloning of the human LDL receptor gene has made it possible to study FH using DNA technology. ${ }^{6}$ There have been at least $\mathbf{4 0}$ different mutations of the LDL receptor gene reported, either gross structural alterations such as deletions or insertions, ${ }^{7-14}$ or those which arise from a single base pair change in the gene. ${ }^{15-18}$ Both of these types of alterations result in an LDL receptor with impaired function, thus causing FH. However, as well as allelic heterogeneity, genetic heterogeneity has recently been shown in $\mathrm{FH}$ patients. In studies in the $\mathrm{UK}^{1920}$ and Germany, ${ }^{21}$ roughly $3 \%$ of patients with a clinical diagnosis of $\mathrm{FH}$ have a defect in the apolipoprotein (apo) B ligand for the receptor, with LDL receptor activity in these patients being within the normal range. ${ }^{22}$ The molecular defect underlying this disorder (familial defective apo $B 100^{23}$ ) is a single base change in the apo B gene causing a substitution of $\mathrm{Arg}_{3500}$ for $G \ln$, in a region of the protein that interacts with the receptor. ${ }^{24}$ The defective binding and clearance of the LDL-Gln ${ }_{3500}$ causes the hypercholesterolaemia observed.

Although in many cases, diagnosis of $\mathrm{FH}$ can be carried out on the basis of a single total cholesterol estimation, there is general agreement that about 10 to $15 \%$ of children could not be diagnosed unequivocally by this means alone. ${ }^{25-27}$ This is because of overlap between plasma lipid values in normal and $\mathrm{FH}$ subjects, although this degree of overlap can be reduced somewhat by determination of LDL cholesterol. ${ }^{25-27}$ In addition, some children sampled before puberty may have cholesterol levels within the normal range for their age and gender and only develop raised cholesterol levels in later years. ${ }^{28}$ Diagnosis in the families of these patients may be greatly assisted by using cell biology or genetic tests. Several methods have been published to determine LDL receptor function in freshly isolated lymphocytes from patients. ${ }^{29-31}$ However, these methods are technically complex, and for all published methods there is not complete discrimination between subjects who have a proven defect in the LDL receptor and those who do not.

For such patients and their relatives, genetic tests would be a useful way to alleviate dia- 
gnostic conundrums. In the UK, detectable gross deletions in the LDL receptor gene are found only in about $5 \%$ of patients, ${ }^{12-14}$ and to date seven different point mutations or small deletions have also been reported. ${ }^{16-18}$ Some of these occur in several apparently unrelated subjects and, taken together, these mutations and deletions accounted for approximately $20 \%$ of the molecular defects in a group of 200 FH patients from London. However, for the remainder of patients, restriction fragment length polymorphisms (RFLPs) of the LDL receptor gene ${ }^{32} 33$ can be used to follow the inheritance of the defective gene in the family, and to identify relatives who have inherited the defective allele. ${ }^{34}$

We report here the use of the polymerase chain reaction (PCR) gene amplification technique to determine the genotype at six variable sites in the LDL receptor gene. We have estimated the extent of linkage disequilibrium between the variable sites, and have used a combination of cellular and genetic techniques to study a family from London, and to identify those subjects who have inherited the defective LDL receptor gene.

\section{Methods}

SELECTION OF SUBJECTS

Patients with a clinical diagnosis of $\mathrm{FH}$ were recruited from lipid clinics in London. The diagnostic criteria used were as previously described $^{3536}$ and, briefly, comprised an increased level of total and LDL cholesterol in plasma (over the 95th centile for the general adult ( $>18$ years) population $(>4.9 \mathrm{mmol} / \mathrm{l})$ ) with a total triglyceride of not more than $2.0 \mathrm{mmol} / 1$, together with tendon xanthomata or premature coronary artery disease in the patient or in a first degree relative.

\section{DETECTION OF THE LDL RECEPTOR RFLPS}

Genomic DNA was isolated from venous blood as previously described. ${ }^{37}$ Fragments of the LDL receptor gene were amplified using the polymerase chain reaction ${ }^{38}$ with the oligonucleotides (Oswell DNA Services, Department of Chemistry, University of Edinburgh, or Severn Biotech Ltd) shown in table 1. The reaction mix contained approximately $500 \mathrm{ng}$ of genomic DNA, 150 to $250 \mathrm{ng}$ of each oligonucleotide (table 1), $200 \mathrm{mmol} / \mathrm{l}$ of each dNTP (BRL), $10 \%$ (v/v) dimethyl sulphoxide, and $0.4 \mathrm{U}$ of $\mathrm{Taq}$ polymerase, in a total volume of $25 \mu \mathrm{l}$ of buffer as recommended by the manufacturer (Perkin-Elmer Cetus, USA). The optimum concentration of magnesium chloride was determined for each oligonucleotide pair, and was between 1.0 and $1.5 \mathrm{mmol} / \mathrm{l}$. Thirty cycles of amplification were carried out in a programmable heating block (Cambio, Cambridge, UK) with denaturing at $95^{\circ} \mathrm{C}$ for one minute, annealing at $55^{\circ} \mathrm{C}$ for one minute $\left(62^{\circ} \mathrm{C}\right.$ for the AvaII oligonucleotides), and extension for one minute at $72^{\circ} \mathrm{C}$. One tenth of the product was analysed by agarose gel electrophoresis (Ultrapure Agarose, BRL, USA) and $15 \mu \mathrm{l}$ of the remainder were digested for 16 hours at $37^{\circ} \mathrm{C}$ with $8 \mathrm{U}$ of the relevant restriction enzyme (Anglian Biotec Ltd, UK) in a total volume of $20 \mu \mathrm{l}$. The digestion mixture was analysed by electrophoresis through an agarose or agarose $/ 2 \%$ NuSieve (FMC Bioproducts, Rockland, USA) gel (table 1), and visualised with ethidium bromide. For the $S f a$ NI variable site in exon 2 the polymorphism was detected by differential oliogonucleotide hybridisation using allele specific oligonucleotides and conditions as described previously. ${ }^{33}$

\section{ASSAY OF LDL RECEPTORS ON LYMPHOBLASTOID} CELLS

Human mononuclear cells were isolated under sterile conditions from fresh blood of a normal donor (MF), a heterozygous familial hypercholesterolaemic patient ( $4 \mathrm{~A}$, deletion in exons 9 and 10 of the LDL receptor gene ${ }^{39}$ ), and from the proband in family $Y$ (II.1) and his brother (II.3) according to the method of Boyum. ${ }^{40}$

The cells were transformed with EpsteinBarr virus as described by Neitzel ${ }^{41}$ and cultured in RPMI-1640 medium (Gibco), penicillin (Seromed) $100 \mathrm{units} / \mathrm{ml}$, streptomycin (Seromed) $100 \mu \mathrm{g} / \mathrm{ml}$, and fetal calf serum (Boehringer) $10 \% \mathrm{v} / \mathrm{v}$. Twenty-four hours

Table 1 Primers and conditions used to amplify region of the $L D L$ receptor gene and fragment sizes generated before and after digestion.

\begin{tabular}{|c|c|c|c|c|c|}
\hline \multirow[t]{2}{*}{ Primer $\left(5^{\prime}-3^{\prime}\right)$} & \multicolumn{2}{|c|}{ Location } & \multicolumn{2}{|c|}{ Fragment size (bp) } & \multirow{2}{*}{$\begin{array}{l}\text { Enzyme for } \\
\text { RFLP }\end{array}$} \\
\hline & & & Undigested & Digested & \\
\hline $\begin{array}{l}\text { CCT TTC TCC TTT TCC TCT CTC TCAG } \\
\text { AAA ATA AAT GCA TAT CAT GCC CAAA }\end{array}$ & $\begin{array}{l}\text { Intron } \\
\text { Intron }\end{array}$ & $\begin{array}{l}1 \\
2\end{array}$ & $\sim 193$ & $\begin{array}{l}34 / 58+101^{*} \\
92+101\end{array}$ & SfaNI \\
\hline ATC TGA CGA GGA AAA CTG CGG & End exon & 4 & 978 & $540 / 430 \dagger$ & TaqI \\
\hline GGC CAC AGC TGG AAA ACA GGA & End intron & 4 & & & \\
\hline ATC GAT GAG TGT CAG GAT CC & Start exon & 8 & 150 & $110 / 40 \ddagger$ & StuI \\
\hline CCC GCC GCC TTC CCG TGC TGA & End exon & 8 & & & \\
\hline $\begin{array}{l}\text { CTT ATC CAC TTG TGT GTC TAG } \\
\text { GAT CTC GTA CGT AAG CCA CAC }\end{array}$ & $\begin{array}{l}\text { Start exon } \\
\text { End exon }\end{array}$ & $\begin{array}{l}12 \\
12\end{array}$ & 180 & $\begin{array}{l}130+50 \ddagger \\
95 / 35+50\end{array}$ & HincII \\
\hline $\begin{array}{l}\text { TTG CTG CCT GTT TAG GAC AAA } \\
\text { CTC TTG GCT GGG TGA GGT TG }\end{array}$ & $\begin{array}{l}\text { Start exon } \\
\text { End exon }\end{array}$ & $\begin{array}{l}13 \\
13\end{array}$ & 157 & $128 / 29 \ddagger$ & AvalI \\
\hline $\begin{array}{l}\text { CAC CTA GTC CTT CCA CTT CTA } \\
\text { TCC CGT CAA ACG ATC CAG ACT }\end{array}$ & $\begin{array}{l}\text { Nt } 3604 \text { exon } \\
\text { Nt } 4520 \text { exon }\end{array}$ & $\begin{array}{l}18 \\
18\end{array}$ & 916 & $430 / 485 \dagger$ & NcoI \\
\hline
\end{tabular}

- Detected in this study by ASO. $\uparrow 1 \%$ agarose. $\ddagger 4 \%$ Nusieve $/ 2 \%$ agarose. 
before the tests, cells were washed with RPMI and preincubated in RPMI-1640 medium supplemented with bovine serum albumin (BSA from $I B F) 10 \mathrm{~g} / 1$ replacing $\mathrm{FCS}$, at a final concentration of $10^{6}$ cells $/ \mathrm{ml}$, to enhance the LDL receptor expression on the cell surface.

Human LDL (density 1.030 to $1.055 \mathrm{~g} / \mathrm{ml}$ ) was isolated from fresh plasma of normal healthy donors by four sequential centrifugation steps ${ }^{42}$ at $100000 \mathrm{~g}$ in a $50 \cdot 2$ TI Rotor in a Beckman L.8 ultracentrifuge at $4^{\circ} \mathrm{C}$ for 24 hours. LDL was radiolabelled with $\left[{ }^{125} \mathrm{I}\right] \mathrm{Na}$ by the iodine monochloride method described by MacFarlane ${ }^{43}$ and modified by Bilheimer et $a l^{44}$ for lipoproteins.

Analysis of the LDL receptor activity was as previously described. ${ }^{45}$ Briefly, the cells were resuspended in the preincubation medium and aliquots of $1 \mathrm{ml}\left(10^{6}\right.$ cells) were prepared in $1.5 \mathrm{ml}$ microfuge tubes. Cells were centrifuged at $1000 \mathrm{rpm}$ for five minutes at $20^{\circ} \mathrm{C}$ in a Jouan CR412 centrifuge. Cells were incubated in multi-well plates at $4^{\circ} \mathrm{C}$ with five different concentrations of $\left[{ }^{125} \mathrm{I}\right]-\mathrm{LDL}(2,5,10,25$, and $50 \mu \mathrm{g} / \mathrm{ml}$ ) in triplicate with $10^{6}$ cells in a final volume of $250 \mu$ l of RPMI + BSA. Non-specific binding was determined in duplicate by adding a 20 fold excess of unlabelled LDL. Cells were incubated at $4^{\circ} \mathrm{C}$ for two hours, the plate was centrifuged for five minutes at 1500 rpm, and the supernatant discarded. The cells were washed twice by centrifugation for five minutes at $1500 \mathrm{rpm}$ with Buffer C (PBS, $0.01 \mathrm{~mol} / \mathrm{l}, \mathrm{CaCl}_{2} 0.5 \mathrm{mmol} / \mathrm{l}$, BSA $2 \% \mathrm{p} / \mathrm{v}$ ). The cell pellet was resuspended in $250 \mu \mathrm{l}$ PBS $0.01 \mathrm{~mol} / 1$ and transferred to tubes, followed by centrifugation for five minutes at $4000 \mathrm{rpm}$. The cell pellet was dissolved in $250 \mu \mathrm{l}$ of $0.1 \mathrm{~mol} / 1 \mathrm{NaOH}$, the cell associated radioactivity was determined, and an aliquot of $100 \mu \mathrm{l}$ was used for protein determination. Binding internalisation and degradation of $\left.{ }^{125} \mathrm{I}\right]-\mathrm{LDL}$ at $37^{\circ} \mathrm{C}$ was determined after four hours at five different concentrations of $\left[{ }^{125} \mathrm{I}\right]$ LDL, as described above, by the procedure of Goldstein and Brown. ${ }^{46}$ The cells were washed

$5^{\prime}$

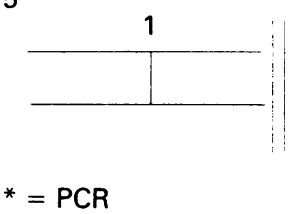

Frequency of cutting allele

Figure 1 Map of the $L D L$ receptor gene showing the position of the six variable sites.

Table 2 Relative rare allele frequency, disequilibrium estimate (above diagonal), and $P I C$ values (below diagonal) between the six RFLPs in $60 \mathrm{FH}$ patients from London.

\begin{tabular}{lcccccc}
\hline & \multicolumn{7}{c}{ Delta } \\
\cline { 2 - 7 } & SfaNI & TaqI & StuI & HincII & AvaII & NcoI \\
\hline Exon & 2 & 6 & 8 & 12 & 13 & 18 \\
Rel freq of + & 0.86 & 0.08 & 0.97 & 0.49 & 0.49 & 0.74 \\
SfaNI & - & 0.08 & 0.03 & 0.07 & 0.07 & -0.09 \\
TaqI & 0.34 & - & -0.05 & $0.29 *$ & $0.29^{*}$ & -0.02 \\
StuI & 0.35 & 0.19 & - & 0.02 & 0.00 & -0.04 \\
HincII & 0.54 & 0.48 & 0.40 & - & $-0.76 \dagger$ & -0.10 \\
AvaII & 0.54 & 0.48 & 0.41 & 0.52 & - & $-0.32^{*}$ \\
NcoI & 0.55 & 0.47 & 0.39 & 0.68 & 0.66 & - \\
\hline
\end{tabular}

Polymorphism information content.

$* p<0.05,+p<0.001$. and treated as previously described for the binding at $4^{\circ} \mathrm{C}$.

\section{STATISTICAL ANALYSIS}

$\chi^{2}$ analysis was used to test the hypothesis of random association between the alleles of two particular RFLPs. Statistical significance was considered to be at the 0.05 level. The correlation coefficient $\Delta$ was used to determine the degree of linkage disequilibrium between two RFLP loci A and B. ${ }^{47}$ Pairwise polymorphism information content (PIC) values were calculated from the observed frequency of the haplotypes in the control population. For subjects heterozygous for both polymorphisms, the relative frequency of the two possible haplotypes was estimated from the frequency of the unambiguously observed haplotypes, using an estimation maximisation algorithm. ${ }^{48}$

\section{Results}

The position in the LDL receptor gene of the six variable sites used in this study is shown in fig 1 . They are located throughout the gene, spanning a total distance of $35 \mathrm{~kb}$ from the most $5^{\prime}$ ( $S f a \mathrm{NI}$, exon 2) to the most 3' (NcoI, exon 18). Five of these variable sites are in exons: SfaNI (exon 2), StuI (exon 6), HincII (exon 12), AvaII (exon 13), and NcoI (exon 18 in the $3^{\prime}$ untranslated region of the mRNA), and only the StuI sites result in an amino acid change in the protein $\left(\mathrm{Ala}_{370}-\mathrm{Thr}\right)$. None of the variable sites affects any known functional sequence of the LDL receptor.

The oligonucleotides used to amplify the fragments of the LDL receptor gene are shown in table 1 . For the $S f a$ NI variable site in exon 2 the resulting fragments are small, and it is more convenient to detect the polymorphism by allele specific hybridisation. Table 2 shows the relative rare allele frequencies for the RFLPs in a sample of 60 unrelated $\mathrm{FH}$ patients from London. For all RFLPs, the observed genotype distribution was that expected for a population in Hardy-Weinberg equilibrium (not shown). The frequencies range from 0.03 (StuI) to approaching 0.5 (AvaII, HincII). However, as shown in table 3 , there is strong linkage disequilibrium between many of the pairwise combinations of RFLPs. By inspection of table 2, it would appear that the combination of HincII, NcoI, and $S f a$ NI would be most informative, and in this sample of 60 patients a total of 51 were heterozygous for one or more of these three polymorphisms, (cumulative frequency $62 \%$, $78 \%$, and $85 \%$ respectively, not shown). No increase in the number of heterozygotes was observed from the use of the StuI RFLP and only one additional subject was heterozygous for the TaqI RFLP.

These RFLPs were used to follow the inheritance of alleles of the LDL receptor gene in the $\mathrm{Y}$ family (fig 2 ). The proband (II-1, table 3) has a clinical diagnosis of $\mathrm{FH}$, with hypercholesterolaemia, coronary artery disease (angina at 35 years), and several first degree relatives with either hypercholesterolaemia or 
Table 3 Chracteristics, age (at sampling in 1989), lipid levels, and NcoI and TaqI genotypes of members of the $Y$ family.

\begin{tabular}{|c|c|c|c|c|c|c|c|}
\hline \multirow{2}{*}{ Pedigree No } & \multirow{2}{*}{ Gender } & \multirow{2}{*}{ Age } & \multirow[b]{2}{*}{$\begin{array}{l}\text { Total chol } \\
(\mathrm{mmol} / \mathrm{l})\end{array}$} & \multirow{2}{*}{$\begin{array}{c}\text { Trig } \\
(\mathrm{mmol} / \mathrm{l})\end{array}$} & \multirow{2}{*}{$\underset{(\mathrm{mmol} / \mathrm{l})}{\mathrm{LDL}}$} & \multicolumn{2}{|c|}{ Genotypes } \\
\hline & & & & & & NcoI & TaqI \\
\hline I.1 & $\mathbf{M}$ & 73 & $7 \cdot 8^{*}$ & $1 \cdot 3$ & - & $+1+$ & $+1-$ \\
\hline I. 2 & $\mathrm{~F}+$ & 65 & $7 \cdot 8^{*}$ & 1.7 & $5 \cdot 7$ & $+1-$ & $-1-$ \\
\hline II.1 & $\mathbf{M}^{\dagger}$ & 41 & $8 \cdot 1^{*}$ & 1.0 & $6 \cdot 0$ & $+1-$ & $+1-$ \\
\hline II. 2 & $\mathrm{~F}$ & 39 & $4 \cdot 4$ & 0.8 & - & $+1-$ & $-1-$ \\
\hline II. 3 & $\mathbf{M}$ & 39 & $9 \cdot 1^{*}$ & 1.4 & $7 \cdot 0$ & $+1+$ & $-1-$ \\
\hline II. 4 & $\mathrm{~F}$ & 42 & $6 \cdot 7$ & 0.5 & 5.0 & $+1-$ & $-1-$ \\
\hline II. 5 & $\mathrm{~F}^{\dagger}$ & 36 & $8 \cdot 7^{*}$ & $0 \cdot 7$ & $6 \cdot 9$ & $+1-$ & $-1-$ \\
\hline II. 6 & M & 34 & $5 \cdot 6$ & 1.0 & $3 \cdot 7$ & $+1+$ & $+1-$ \\
\hline III.1 & $\mathbf{M}$ & 7 & 4.8 & 0.4 & $2 \cdot 9$ & $+1-$ & $+1-$ \\
\hline III. 2 & M & 3 & $5 \cdot 4^{*}$ & $1 \cdot 3$ & $4 \cdot 0$ & $+1+$ & $+1-$ \\
\hline III. 3 & $M$ & 8 & 4.9 & 0.4 & $2 \cdot 7$ & $+1-$ & $-1-$ \\
\hline III. 5 & $M$ & 6 & 4.5 & 0.4 & $2 \cdot 8$ & $+1+$ & $+1-$ \\
\hline III. 6 & M & 2 & $5 \cdot 7^{*}$ & $1 \cdot 3$ & 3.8 & $+1+$ & $+1+$ \\
\hline
\end{tabular}

* Cholesterol over 95 th centile for age and gender, as estimated from data in ref 28

† Lipid levels on cholestyramine treatment, untreated lipid levels unavailable. Symptoms of ischaemic heart disease detected in I.2, angina aged 44 years, and in II.3, angina aged 35 years.

CAD (table 3). He originally approached us with a request for diagnosis for his two sons, both of whom have raised total and LDL cholesterol levels for their age and gender ( $>75$ th centile, III.1, $>95$ th centile III.2) as do the sons of his sister, II.5. Genotypes for several RFLPs were determined and the results for NcoI and TaqI are shown in fig 2. The affected mother of the proband is heterozygous for the NcoI RFLP and the N-allele has been inherited by the proband and his hypercholesterolaemic sister (II.5) but not by his hypercholesterolaemic brother (II.3). There is thus no correspondence between the inheritance of hyperlipidaemia and a particular allele of the LDL receptor and this raised the possibility that the hypercholesterolaemia in one or more of these subjects was not the result of a defect in the LDL receptor. None of these subjects was a carrier of the apo B $\mathrm{Arg}_{3500}$-Gln mutation (not shown), and LDL from the proband and his brother bound with normal affinity to LDL receptors in a U937 growth assay (J Frostegard, J Nielson, A Hamsten, unpublished data). Using RFLPs of the apo $B$ gene, cosegregation could not be shown between alleles of the apo B gene and the hyperlipidaemia (not shown). Inspection of the LDL receptor and apo B RFLP data showed no evidence of biological inconsistency.

To examine this further, lymphoblastoid cell lines were established from the proband and his brother. LDL receptor function was compared to that of a cell line from a normal subject (MF) and from an $\mathrm{FH}$ patient from Iceland (4A), who was heterozygous for a deletion of exon 9-10 of the LDL receptor gene, and thus served as an unambiguous LDL receptor defective control. Assays were carried out to determine binding of LDL to the four cell lines at $37^{\circ} \mathrm{C}$ and $4^{\circ} \mathrm{C}$ using $\left[{ }^{125} \mathrm{I}\right]-$ LDL. The results from all assays were consistent and those from the $4^{\circ} \mathrm{C}$ binding are shown in fig 3. Binding to the cells from the proband was consistently low and similar to that of the $\mathrm{FH}$ cell line. Binding to the cells from the brother (II.3) was consistently high and similar to that seen for the normal cell line (MF). This suggests that the proband is heterozygous for a defect in the LDL receptor, while in his brother, LDL receptor function is within the normal range.

By inspection of the pedigree, the defective allele of the LDL receptor gene that has been inherited from the mother by the proband and his sister (but not by the brother) appears to

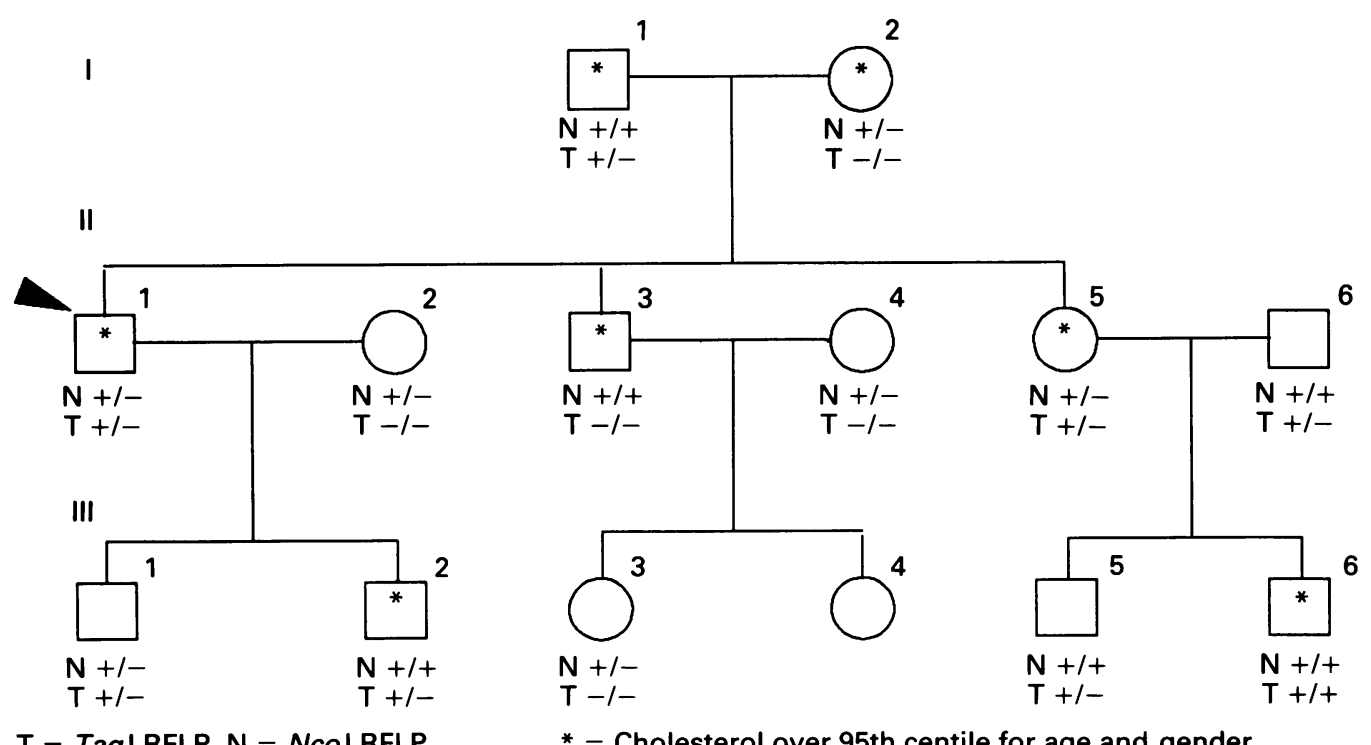

T = TaqI RFLP, $\mathbf{N}=$ Ncol RFLP

* $=$ Cholesterol over 95th centile for age and gender

Figure 2 Pedigree of the Y family. Cholesterol levels ( $\mathrm{mmol} / \mathrm{l}$ ) in the family members. Subjects with cholesterol levels over the 95th centile for their age and gender are indicated by *. Genotypes for the NcoI and TaqI RFLPs are shown. The proband is indicated with an arrow. 


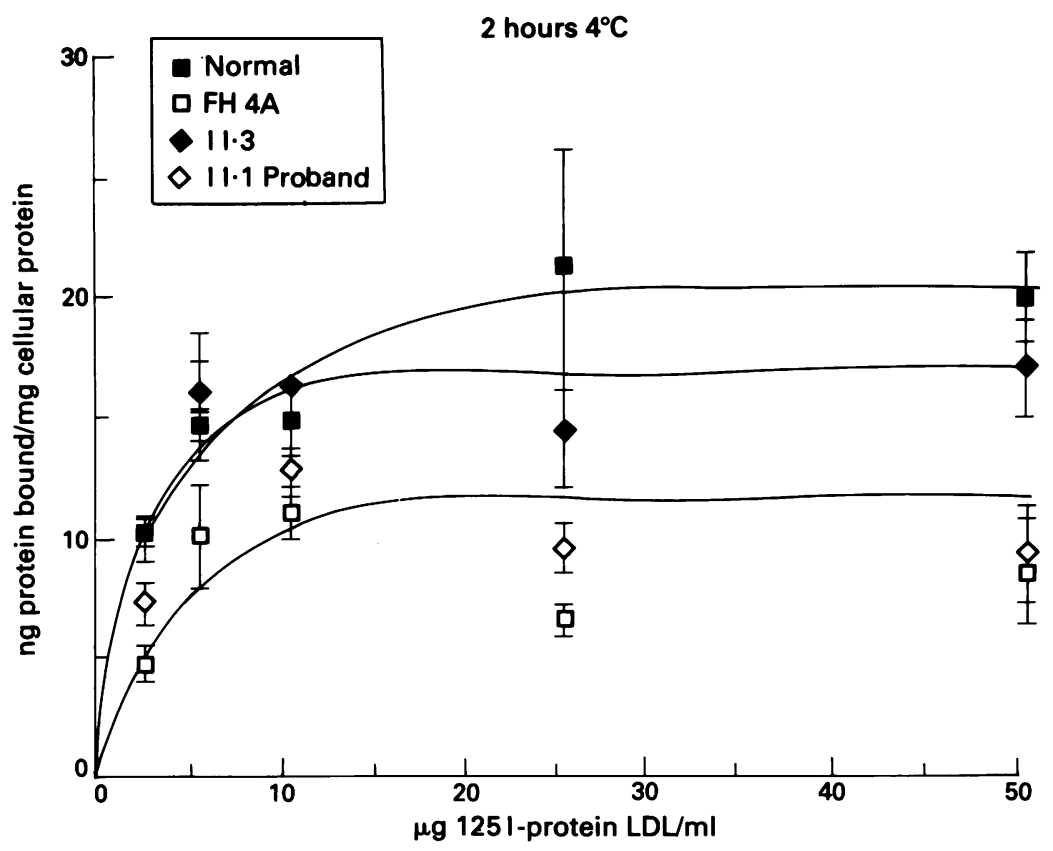

Figure 3 Study of $L D L$ receptor activity at $4^{\circ} \mathrm{C}$ with $[125 I]-L D L$. Data from a normal subject (MF), LDL receptor deletion $F H$ heterozygous patient $(4 A)$, and subjects II.1 and II.3 from the $Y$ family are shown. Cells that have been precincubated for 24 hours in RPMI+BSA were incubated with [ $\left.{ }^{225} I\right]-L D L$ for two hours at $4^{\circ} \mathrm{C}$. were incorrectly classified as ' $\mathrm{FH}$ ' or 'normal' by lipid values alone.

Until recently, diagnosis of $\mathrm{FH}$ in children has been in question only in the 10 to $15 \%$ of subjects whose total or LDL cholesterol levels fall within the 'overlap' of the bimodal distributions observed in first degree relatives of subjects with $\mathrm{FH} .{ }^{25-27}$ However, a recent longitudinal study indicated that there are children at risk for FH in whom total or LDL cholesterol levels may initially be well within the normal range, and may subsequently rise to levels at which diagnosis of $\mathrm{FH}$ would have been made unequivocally using conventional criteria. ${ }^{28}$ Both of these problems can be overcome by the application of genetic tests. In patients in the UK, a number of gross deletions, small deletions, and point mutations have been reported, explaining in total only $20 \%$ of the defects in 200 patients studied in London, ${ }^{1416-18}$ and thus in the majority of patients the molecular defect is still unknown. The main aim of this study was therefore to determine the usefulness of six RFLPs of the LDL receptor gene as cosegregation markers for diagnosis in families with known FH.

The usefulness of such polymorphisms depends on the relative frequency of the alleles and the degree of linkage disequilibrium between the alleles of the different polymorphisms. We have previously reported similar studies using Southern blotting methods and the enzymes NcoI, ApaLI, PvuII, and StuI, ${ }^{53}$ showing an overall heterozygosity index of $0 \cdot 7$ with a combination of $A v a \mathrm{II}$ and $\mathrm{NcoI}$ being the most useful pair (PIC 0.61). However, the $A p a \mathrm{LI}$ and PvuII variable sites are located in the $5 \mathrm{~kb}$ long intron 15 , and we have been unable to amplify this intron using primers for exon 15 and 16 (unpublished data). For the six RFLPs used in the current study, the combination of HincII and $\mathrm{NcoI}$ gives the highest pairwise PIC valve of 0.68 , and with the addition of the $S f a$ NI RFLP, $85 \%$ of patients in the sample were heterozygous for at least one polymorphism. Although the $S f a N I$ RFLP is of low frequency (rare allele frequency $0 \cdot 14$ ), the extent of the linkage disequilibrium with the other polymorphism is also low, with the presence of the (rare) $S f a \mathrm{NI}$ 'no cutting' site being found most frequently on the haplotype containing the common allele for the HincII and NcoI RFLPs (not shown). As expected from our previous studies, ${ }^{53}$ the low frequency of the StuI variable site (reported as 0.06 to $0.03)^{5253}$ means that, in general, it is of little use in family investigations. Recently, variable copy dinucleotide repeat polymorphisms have been reported in the LDL receptor gene. ${ }^{5455}$ Although technically more difficult than the PCR methods we present here, these polymorphisms should also be useful for family studies.

The investigation in the $\mathrm{Y}$ family illustrates a number of the problems that may be encountered in attempting to identify familial hypercholesterolaemia in the relatives of a patient with a clinical diagnosis of $\mathrm{FH}$. With an estimated population carrier frequency of defects causing $\mathrm{FH}$ of $1 / 500$, families where both parents have LDL receptor defects are rare. determine hypercholesterolaemia (lipid levels above the 95 th centile). This misclassification was reduced using age and gender specific lipid values, but there were still $5 \%$ of relatives who 
However, there are many other genetic and environmental factors that cause hyperlipidaemia, and familial aggregation of these environmental factors and segregation of other undetected genetic variants may complicate the unequivocal identification of the defective LDL receptor allele. This appears to be the case in family $Y$, where it may be that a mutation in a gene (or combination of genes) causing hyperlipidaemia has been inherited (possibly from the grandfather (I.1)) by several of the family members (II.3, III.2, and III.6). The use of the LDL binding assay allowed the inheritance of the defective allele to be inferred in this family. Although the cosegregation analysis showed that none of the four children in generation III had inherited the defective allele of the LDL receptor from the grandmother, it leaves unresolved the reason for the hypercholesterolaemia seen in III.2 and III.6.

With the availability of many RFLPs of the LDL receptor gene, the main factors determining the success of diagnosis by a family cosegregation approach are uncertainty in the diagnosis, caused by individual differences in genetic background or environmental factors, unavailability (owing to premature death) of affected relatives to determine phase, and the confounding problem of non-paternity. In situations of doubt, paternity can be confirmed using genetic tests, ${ }^{56}$ and cosegregation study of families of patients with FH from Munich has recently shown that diagnosis was possible in all cases where samples from four or more relatives were available, ${ }^{57}$ though this depends on the pedigree structure. In the $\mathrm{Y}$ family the analysis required the determination of LDL receptor function in the proband and his hypercholesterolaemic brother. This shows the usefulness of the cell LDL receptor assay and the complementary nature of the cellular and genetic tests. To date, no cell assay of LDL receptor function allows an unambiguous distinction between cells from normal and LDL receptor defective subjects. In the next few years, it is increasingly likely that the problems of diagnosis by family studies will be avoided by the identification of specific mutations in the LDL receptor gene. Rapid methods such as SSCP $^{55}$ for identifying new mutations in individual patients will be useful in the future, but until these become routine, unequivocal identification of carriers and noncarriers in the relatives of $\mathrm{FH}$ patients may be aided by cosegregation studies using the RFLPs described here.

This work was supported by the Sunley Research Trust and grants from the British Heart Foundation (RG16) and INSERM U325. VG was a fellow of the Icelandic Council of Science. We thank Drs J Frostegard, J Nielson, and A Hamsten (Karolinska Institute, Sweden) for assaying the binding ability of LDL from the members of the $\mathrm{Y}$ family, Elaine Osman and Gina Deeley for preparation of the manuscript, and the members of the $\mathrm{Y}$ family for their help.

1 Brown MS, Goldstein JL. Familial hypercholesterolaemia In: Stanbury JB, Wyngaarden JB, Frederickson DS,
Goldstein JL, Brown MS, eds. The metabolic basis of inherited human disease. New York: McGraw Hill, 1983:500-50.

2 Slack J. Risks of ischaemic heart disease in familial hyperlipoproteinaemic states. Lancet 1969;ii:1380-2.

3 Goldstein JL, Hazzard WR, Schrott HG, Bierman EL, Motulsky AG. Hyperlipidaemia in coronary heart disease. Part I. Lipid levels in 500 survivors of myocardial infarction. $\mathcal{f}$ Clin Invest 1973;52:1533-43.

4 Goldstein JL, Brown MS. The LDL receptor defect in familial hypercholesterolaemia. Implications for the pathogenesis and therapy. Med Clin North Am 1982;66:33562 .

5 Tolleshaug H, Hobgood KK, Brown MS, Goldstein JL. The LDL receptor locus in familial hypercholesterolaemia - multiple mutations disrupt transport and processing of a membrane receptor. Cell 1983;32:941-51.

6 Yamamoto T, Davis LG, Brown MS et al. The human LDL-receptor: a cystein-rich protein with multiple Alu sequences in its mRNA. Cell 1984;39:27-38.

7 Lehrman MA, Schneider WS, Sudhof TC, Brown MS Goldstein JL, Russell DW. Mutation in LDL receptor: Alu-Alu recombination deletes exons encoding transmembrane and cytoplasmic domains. Science 1985;227:140-6.

8 Horsthemke B, Kessling AM, Seed M, Wynn V, Williamson $\mathrm{R}$, Humphries SE. Identification of a deletion in the low density lipoprotein (LDL) receptor gene in a patien with familial hypercholesterolaemia. Hum Gene 1985;71:75-8.

9 Hobbs HH, Brown MS, Russell DW, Davignon J, Goldstein JL. Deletion in the gene for the low-density-lipoprotein receptor in a majority of French Canadians with familial hypercholesterolemia. $N$ Engl $f$ Med 1987;12:734-7.

10 Aalto-Setala K, Gylling H, Miettinen T, Kontula K. Identification of a deletion in the LDL receptor gene. A tification of a deletion in the LDL receptor gene.
Finnish type of mutation. FEBS Lett 1988;230:31-4.

11 Top B, Koeleman BPC, Gevers Leuven JA, Havekes LM Frants RR. Rearrangements in the LDL receptor gene in Dutch familial hypercholesterolaemic patients: presence of a common 4kb deletion. Atherosclerosis 1990;83:12736

12 Horsthemke B, Dunning A, Humphries S. Identification of deletions in the human low density lipoprotein (LDL) receptor gene. $\mathcal{F}$ Med Genet 1987;24:144-7.

13 Horsthemke B, Beisiegel U, Dunning A, Havinga JR, Williamson R, Humphries SE. Unequal crossing-over between two alu-repetitive DNA sequences in the lowdensity-lipoprotein-receptor gene. Eur f Biochem 1987;164:77-81.

14 Sun XM, Webb JC, Gudnason V, et al. Characterisation of deletions in the LDL receptor gene in patients with deletions in the LDL receptor gene in patients with
familial hypercholesterolemia in the United Kingdom. familial hypercholesterolemia in the U
Arteriosclerosis Thromb 1992;12:762-70.

5 Hobbs HH, Russell DW, Brown MS, Goldstein JL. The LDL receptor locus in familial hypercholesterolemia mutational analysis of a membrane protein. Annu Rev Genet 1990;24:133-70.

16 King-Underwood L, Gudnason V, Humphries SE, et al. Identification of the 664 proline to leucine mutation in the low density lipoprotein receptor in four unrelated patients with familial hypercholesterolaemia in the UK. Clin Genet 1990;40:17-28.

17 Webb JC, Sun XM, Patel DD, McCarthy SN, Knight BL Soutar AK. Characterisation of two new point mutations in the low density lipoprotein receptor genes of an English patient with homozygous familial hypercholesterolemia. $\mathscr{f}$ Lipid Res 1992;33:689-98.

18 Gudnason V, King-Underwood L, Seed M, Sun XM, Soutar AK, Humphries SE. Identification of recurren and novel mutations in exon 4 of the low density lipoprotein receptor gene in patients with familial hypercholesterolaemia in the UK Arteriosclerosis Thromb (in press).

19 Tybjaerg-Hansen A, Gallagher J, Vincent J, et al. Familia defective apolipoprotein B-100: detection in the United Kind Kingdom and Scandinavia and clinical cha

20 Talmud P, Tybjaerg-Hansen A, Bhatnagar D, Mbewu A Miller JP, Humphries S. Rapid screening for specific Miller JP, Humphries S. Rapid screening for specific mutations in patients with a clinical diagnosis of familial

21 Schuster H, Rauh G, Kormann B, et al. Familial defective apolipoprotein B-100: comparison with familial hypercholesterolaemia in 18 cases detected in Munich. Arteriosclerosis 1990;10:1-6.

22 Myant NB, Gallagher JJ, Knight BL, et al. Clinical signs of familial hypercholesterolaemia in patients with familial defective apolipoprotein B-100 and normal low-density lipoprotein receptor function. Arteriosclerosis Thromb 1991;11:691-703.

23 Innerarity TL, Weisgraber KH, Arnold KS, et al. Familial defective apolipoprotein B-100: low density lipoprotein with abmormal receptor binding. Proc Natl Acad Sci with abnormal receptor

24 Soria LF, Ludwio EH, Clarke HRG, Vega GL, Grundy SM, McCarthy BJ. Association between a specific apoliSM, McCarthy BJ. Association between a specific apolipoprotein B mutation and familial defective apolipopro-

25 Leonard JV, Whitelaw AGL, Wolff OH, Lloyd JK, Slack J. Diagnosing familial hypercholesterolaemia in children by measuring serum cholesterol. BMF 1977;i:1566-8.

26 Kwiterovich PO, Fredrickson DS, Levy RI. Familial hypercholesterolaemia (one form of familial type II hyperlipoproteinaemia)-a study of its biochemical, gen- 
etic and clinical presentation in childhood. $\mathcal{f}$ Clin Invest 1974;53:1237-49.

27 Kwiterovich PO. Pediatric implications of heterozygous familial hypercholesterolemia. Screening and dietary treatment. Arteriosclerosis 1989;9(suppl 1): I-111-I-120.

28 Kessling AM, Seed M, Taylor R, Wynn V, Humphries SE Rising cholesterol levels in children with familial hypercholesterolaemia. Biomed Pharmacother 1990;40:373-9.

29 Cuthbert JL, East CE, Bilheimer DW, Lipsky PE. Detection of familial hypercholesterolemia by assaying function of familial hypercholesterolemia by assaying func-
tional low-density lipoprotein receptors on lymphocytes. tional low-density lipoprotein

30 Benhamamouch S, Kusnierz JP, Agnani G, et al. Determination of the LDL receptor binding capacity of human lymphocytes by immunocytofluorimetric assay. Biochim Biophys Acta 1988;1002:45-53.

31 Schmitz G, Wolf D, Brunning T, Assman G. Detection of LDL-binding sites on human white blood cells by flow cytometry. Clin Chem 1987;33:2195-202.

32 Leitersdorf E, Chakravarti A, Hobbs HH. Polymorphic DNA haplotypes at the LDL receptor locus. $A m \mathcal{F}$ Hum Genet 1989;44:409-21.

33 Soutar AK. A polymorphism in exon 2 of the human LDI receptor gene (LDLR). Nucleic Acids Res 1991;19:4314.

34 Humphries SE Taylor R Jeenah M et al Gene probes in the diagnosis of familial hypercholesterolaemia. Arteriothe diagnosis of familais
sclerosis 1989;9:59-65.

35 Humphries SE, Donald JA, McFadden JJP et al. The use of polymorphic DNA and protein markers for the third component for determining linkage of familial

36 Study Group, European Atherosclerosis Society. The recognition and management of hyperlipidaemia in adults: a policy statement of the European Atherosclerosi Society. Eur Heart $\mathcal{f}$ 1988;9:571.

37 Kunkel LM, Smith KD, Boyer SH, et al. Analysis of human Y-chromosome specific reiterated DNA in chromosome variants. Proc Natl Acad Sci USA 1977;74:1245-9.

38 Saiki RK, Walsh PS, Levenson CH, Erlich HA. Genetic analysis of amplified DNA with immobilized sequencespecific oligonucleotide probes. Proc Natl Acad Sci USA 1989;86:6230-4.

39 Taylor R, Bryant J, Gudnason V, Sigurdsson G, HumphTaylor R, Bryant J, Gudnason V, Sigurdsson G, Humph-
ries SE. A study of familial hypercholesterolaemia in ries SE. A study of familial hypercholesterolaem

40 Boyum A. Isolation of mononuclear cells and granulocytes from human blood. Scand $\mathcal{Y}$ Clin Lab Invest 1968;97:7789.

41 Neitzel H. A routine method for the establishment of permanent lymphoblastoid cell lines. Hum Genet 1986;73:320-6.

42 Havel RJ, Eder HA, Bragdon JH. The distribution and chemical composition of ultracentrifugally separated lipoproteins in human serum. $\mathcal{f}$ Clin Invest 1985;34:1345-53.

43 Macfarlane AS. Efficient trace-labelling of proteins with iodine. Nature 1958;182:53-8.
44 Bilheimer DW, Eisenberg S, Levy RI. The metabolism of very low density lipoproteins. Biochim Biophys Acta 1972;260:212-21.

45 Delattre S, Clavey V, King-Underwood L, Kusnierz JP, Humphries S, Fruchart JC. LDL receptor deficiency determined on Epstein-Barr virus transformed lymphocytes. Methods Mol Cell Biol 1991;2:221-7.

46 Goldstein JL, Brown MS. Binding and degradation of low density lipoproteins by cultured human fibroblasts. $\mathcal{f}$ Biol Chem 1974;249:5153-62.

47 Chakravati A, Buetow KH, Antonarakis SE, Weber PG, Boehm CH, Kazazian HK. Non-uniform recombination within the human $\beta$-globin gene cluster. Am f Hum Genet 1984;36:1239-58.

48 Templeton AR, Sing CF, Kessling A, Humphries SE. A cladistic analysis of phenotype associations with haplotypes inferred from restriction endonuclease mapping. II. types inferred from restriction endonuclease mapping. II. A4.

49 Christensen B, Glueck C, Kwiterovich P, et al. Plasma cholesterol and triglyceride distributions in 13,665 children and adolescents: the prevalence study of the lipid research clinics programme. Pediatr Res 1980;14:194202.

50 Tamir I, Heiss G, Glueck CJ, Christensen B, Kwiterovich $\mathrm{P}$, Rifkind BM. Lipid and lipoprotein distributions in white children ages 6-19 year. The Lipid Research Clinics Program Prevalence Study. F Chron Dis 1981;34:2739 .

51 Committee on atherosclerosis and hypertension in childhood of the council of cardiovascular disease in the young, and the nutrition committee of the American Heart Association. Diagnosis and treatment of primary hyperlipidaemia in childhood. Arteriosclerosis 1986;6:685-92.

52 Koivisto PVI, Koivisto UM, Miettinen TA, Kontula K. Diagnosis of heterozygous familial hypercholesterolemia. DNA analysis complements clinical examination and analysis of serum lipid levels. Arteriosclerosis Thromb analysis of serum

53 Taylor R, Jeenah $M$, Seed $M$, Humphries S. Four DNA polymorphisms in the LDL receptor gene: their genetic relationship and use in the study of variation at the LDL receptor locus. 7 Med Genet 1988;25:653-9.

54 Zuliani G, Hobbs HH. Dinucleotide repeat polymorphism at the $3^{\prime}$ end of the LDL receptor gene. Nucleic Acids Res 1990;18:4300.

55 Orita $M$, Sekiya T, Hayashi K. DNA sequence polymorphisms in Alu repeats. Genomics 1990;8:271-8.

56 Jeffreys AJ, Brookfield JFY, Semeonoff R. Positive identification of an immigration test-case using human DNA finger-prints. Nature 1985;317:818-9.

57 Schuster H, Steifenhofer B, Wolfram G, et al. Four DNA polymorphisms in the LDL-receptor gene and their use in diagnosis of familial hypercholesterolemia. Hum Genet 1992;82:69-72. 